\title{
A política externa brasileira e os desafios da cooperação Sul-Sul
}

MARIA REGINA SOARES DE LIMA*

Rev. Bras. Polít. Int. 48 ( I): 24-59 [2005]

\section{Introdução}

A África do Sul, o Brasil e a Índia são considerados países intermediários. Ainda que não exista acordo entre os especialistas com relação à definição precisa do conceito, este geralmente inclui pelo menos um dos três fatores: capacidades materiais, uma medida de autopercepção e o reconhecimento dos outros Estados, em especial das grandes potências. Estes três países têm uma característica comum, são "potências regionais" e tal condição lhes assegura uma relevância internacional adicional. Ainda que o conceito tenha sido grandemente utilizado na década de 1970, quando os grandes países em desenvolvimento desenvolviam políticas assertivas no plano internacional, este ainda tem importância no mundo globalizado e unipolar. Na verdade, esta categoria de países pode ser pensada como representando dois perfis internacionais particulares, a partir de duas identidades internacionais distintas.

A primeira, referida ao mundo da política, poderia ser denominada de system-affecting state a partir da conhecida definição de Keohane (1969). Nesta categoria estão aqueles países que dispondo de recursos

\footnotetext{
* Professora do Instituto Universitário de Pesquisa do Rio de Janeiro - Iuperj e do Instituto de Relações Internacionais da Pontifícia Universidade Católica do Rio de Janeiro - IRI-PUC/ Rio (mrslima@iuperj.br). Agradeço à Verônica Cruz pela coleta dos dados e organização das tabelas.
} 
e capacidades relativamente limitadas, comparativamente às potências, mas com perfil internacional assertivo valorizam as arenas multilaterais e a ação coletiva entre países similares de forma a exercer algum meta de poder e influenciar nos resultados internacionais. ${ }^{1}$ Nestes foros, em especial naqueles em que o consenso é necessário para a decisão ou que prevalece o princípio da igualdade da participação, geralmente são interlocutores relevantes, em particular como mediadores entre os grandes e os pequenos. ${ }^{2}$ A segunda identidade, referida à economia global, é a de "grande mercado emergente", categoria cunhada pelo US Trade Representative, que faz referência aos grandes países da periferia que implementaram as reformas econômicas do conhecido receituário do Consenso de Washington: privatização, liberalização comercial, desregulamentação da economia e reforma do Estado. Índia, Indonésia, África do Sul, Coréia do Sul, Turquia, Polônia, Rússia, Argentina, Brasil e México foram definidas como pertencentes a esta categoria (Sennes, 2001: 64) Nesta identidade, credibilidade e estabilidade macroeconômica são duas moedas de grande valor no mundo globalizado e as iniciativas internacionais são pensadas como mecanismos para "encapsular" (lock in) as reformas domésticas. A ação coletiva com paises semelhantes geralmente é subestimada, até porque prevalece a cooperação com os países desenvolvidos.

Nos anos 60 e 70 países como a Índia, o Brasil e o México eram considerados system-affecting states, na medida em que tinham presença internacional multifacetada, participavam de vários foros de negociação comercial e de segurança no Gatt e nas Nações Unidas e eram reconhecidos como interlocutores válidos. Comum entre eles, a articulação de suas políticas externas em torno de dois objetivos centrais: desenvolvimento econômico e autonomia política (Sennes, 2001: 44). A África do Sul não estava incluída neste grupo uma vez que, até a década de 1990, o sistema de apartheid praticamente excluiu aquele país da coalizão terceiro-mundista. Atualmente, porém, todos os quatro são identificados como mercados emergentes. Isto estaria indicando que o

\footnotetext{
${ }^{1} \mathrm{O}$ exercício de "meta poder" por parte dos países influentes da periferia foi examinado por Krasner (1985).

${ }^{2}$ Ver, Hirst (2004) e Sennes (2001: 1-42) para argumentos semelhantes.
} 
primeiro conceito não tem mais referente empírico e, portanto, perdeu relevância analítica? Do meu ponto de vista, a resposta é não; ambos continuam a ter referente e relevância.

Porém, há que se levar em conta que no contexto de hegemonia dos mercados, crise dos modelos de desenvolvimento da periferia e fim da rivalidade Leste-Oeste, não apenas as negociações Norte-Sul, palco do protagonismo político da coalizão terceiro-mundista, e a cooperação SulSul, espaço de afirmação da identidade daquela coalizão, se modificaram profundamente, como alguns dos países que integraram no passado a categoria dos system-affecting countries, hoje, se acomodaram na condição de mercados emergentes. Outros, porém, estão buscando compatibilizar estes dois perfis internacionais. Meu principal objetivo neste trabalho é demonstrar que o Brasil busca conciliar estas duas identidades, mesmo em um contexto de graves restriçôes sistêmicas, econômicas e políticas. Meu secundo objetivo é sugerir que a viabilidade da cooperação IBSA depende exatamente da compatibilidade, "tensionada" é verdade, destes dois perfis internacionais. Em certo sentido, uma das estratégias discursivas dos países hegemônicos é postular estes dois papéis como contraditórios, no caso dos países periféricos. É como se observássemos uma volta ao século passado, aos anos 20 , mais especificamente, quando as potências faziam a distinção na estrutura decisória da Liga das Nações entre as potências com interesses gerais e os países com interesses particulares. Apenas aos primeiros estava reservado protagonismo político nas arenas globais.

\section{As bases regionais e institucionais da política externa brasileira}

Conhecer a inserção geopolítica do Brasil é crucial para se entender a definição de seus interesses nacionais, entendidos os últimos como as orientações substantivas das políticas internacionais do país, bem como a visão da elite pertencente à comunidade de política externa. ${ }^{3}$ Um dos principais vetores da inserção internacional do país tem sido

\footnotetext{
${ }^{3}$ Para o conceito de comunidades de política externa, ver o trabalho de Amaury de Souza (2002). A categoria inclui os membros do Executivo, Congresso e Judiciário, lideranças empresariais, sindicais e de movimentos sociais, representantes de organizações não-governamentais, jornalistas e acadêmicos.
} 
sua localização no Hemisfério Ocidental, historicamente uma área da projeção de poder e influência econômica e cultural dos Estados Unidos, mas que, com exceção da Segunda Guerra Mundial, de escasso valor estratégico na política externa daquele país. Por outro lado, o Brasil tem se deparado com um contexto geopolítico regional estável, uma vez que já no final do século XIX e início do XX, havia resolvido a seu favor praticamente todos os conflitos territoriais com seus vizinhos, a ponto de se autodenominar um "país geopoliticamente satisfeito". Em certo sentido e ao contrário de seus vizinhos, o processo de construção do Estado brasileiro foi realizado antes, pelo recurso à negociação diplomática do que pela guerra. Finalmente, desde a segunda metade do século XX, o Brasil ocupa uma posição econômica dominante com relação aos demais países sul-americanos.

A tabela 1, a seguir, apresenta dados sobre o Produto Interno Bruto dos países sul-americanos, desde 1999. Ainda que se observe uma tendência de queda, em valores absolutos, do PIB de praticamente todos os países, a diferença do peso econômico do Brasil com relação aos demais é significativa, não apenas no ordenamento regional, mas também mundial. Na região latino-americana, o Brasil é ultrapassado apenas pelo México.

\section{Tabela 1}

PIB da América do Sul (1999-2004, em US\$ bilhões)

\begin{tabular}{c|c|l|c|c|c|c|c|c}
\hline $\begin{array}{c}\text { Ordenamento } \\
\begin{array}{c}\text { América Latina } \\
2003\end{array}\end{array}$ & $\begin{array}{c}\text { Ordenamento } \\
\text { Mundial } \\
2003\end{array}$ & País & 1999 & 2000 & 2001 & 2002 & 2003 & $\begin{array}{c}2004 \\
\text { (estimativa) }\end{array}$ \\
\hline $2^{\circ}$ & $15^{\circ}$ & Brasil & 524,07 & 599,81 & 502,94 & 451,80 & 497,85 & 558,40 \\
$3^{\circ}$ & $36^{\circ}$ & Argentina & 283,52 & 584,20 & 268,70 & 92,95 & 129,74 & 149,68 \\
$4^{\circ}$ & $41^{\circ}$ & Venezuela & 103,31 & 121,26 & 126,16 & 94,34 & 84,91 & 90,19 \\
$5^{\circ}$ & $46^{\circ}$ & Colômbia & 80,89 & 83,79 & 81,72 & 81,12 & 77,85 & 88,80 \\
$6^{\circ}$ & $49^{\circ}$ & Chile & 72,95 & 74,87 & 68,42 & 67,37 & 72,05 & 88,20 \\
$7^{\circ}$ & $51^{\circ}$ & Peru & 50,66 & 52,57 & 53,61 & 56,37 & 60,63 & 65,58 \\
$8^{\circ}$ & $62^{\circ}$ & Equador & 16,67 & 15,93 & 21,02 & 24,28 & 27,13 & 29,63 \\
$14^{\circ}$ & $88^{\circ}$ & Uruguai & 20,91 & 20,09 & 18,56 & 12,28 & 11,20 & 12,18 \\
$16^{\circ}$ & $97^{\circ}$ & Bolívia & 8,25 & 8,36 & 8,06 & 8,20 & 8,57 & 8,91 \\
$18^{\circ}$ & $112^{\circ}$ & Paraguai & 7,76 & 7,73 & 6,86 & 5,63 & 5,78 & 6,44 \\
\hline
\end{tabular}

Fonte: FMI - 2003. 
Esta situação peculiar de situar-se no quintal da área de influência norte-americana e, simultaneamente, constituir-se na potência econômica regional em um contexto geopolítico estável, gerou um sentimento peculiar entre as elites brasileiras. As definições de ameaças externas e as percepçôes de risco são basicamente derivadas de vulnerabilidades econômicas e não de segurança. Sendo as principais vulnerabilidades, na visão das elites, de natureza econômica, a política externa sempre teve um forte componente desenvolvimentista. Na verdade, esta última tem sido considerada como um dos principais instrumentos para propósitos de desenvolvimento.

A industrialização brasileira ocorreu de fato a partir da segunda metade do século XX, e constituiu um dos casos mais bem sucedidos, entre os países em desenvolvimento, do modelo de industrialização por substituição de importações, cuja inspiração intelectual foi a teoria de desenvolvimento da Cepal e cujas principais características eram forte indução estatal, relativa discriminação com relação às importações e participação do investimento estrangeiro nos diversos setores industriais. Nos anos 60 e 70, adicionou-se um componente exportador a esta estratégia de desenvolvimento. A política externa foi um instrumento importante deste modelo, não apenas demandado tratamento diferencial no âmbito do regime de comércio e da constituição de um Sistema de Preferências Generalizado nos países desenvolvidos, bem como abrindo novos mercados e oportunidades de cooperação econômica nos países do Sul.

Padrôes de desenvolvimento criam novas idéias, interesses e instituições e uma vez iniciado um deles é muito difícil mudar as instituições e os interesses. Algumas vezes, as condições internacionais que induziram uma determinada trajetória podem se modificar sem que se modifiquem as instituiçóes, interesses e idéias vinculados à trajetória prévia. Padrões de desenvolvimento são trajetória dependente. No caso brasileiro, esta constatação não poderia ser mais verdadeira. Exatamente por ter sido um caso de sucesso na criação de um parque industrial complexo, a mudança de trajetória só vai ocorrer nos anos 90, diante de graves restriçóes econômicas e políticas sistêmicas e da crise fiscal do Estado. Mas assim mesmo, o processo de ajuste estrutural e reforma econômica foi mais incremental, comparando-se com os casos 
da Argentina e México, na América Latina. Ainda que o Ministério de Relações Exteriores não tenha sido uma das instituições criadas pelo padrão de desenvolvimento orientado para dentro, esta agência foi crucial na sustentação e consolidação externa daquele modelo. Duas implicações daí decorrem: por um lado, a legitimidade doméstica desta agência na sua qualidade de um dos instrumentos do projeto de desenvolvimento do país, por outro, o legado desenvolvimentista presente na memória institucional do MRE, que permaneceu mesmo depois da crise e término daquele modelo.

No plano das instituições políticas, o país é uma república presidencialista federativa. A combinação de um sistema de governo presidencialista, sistema multipartidário e de representação proporcional, gerou o que os analistas políticos denominam um "presidencialismo de coalizão” (Santos, 2003). Ainda que a Constituição brasileira assegure ao Executivo amplos poderes de decreto, esta combinação de fatores gera a necessidade da formação de coalizões de governo, tal como no sistema parlamentar. Esta prática tem contribuído para a estabilidade democrática, permitindo que ocorra rotatividade entre as principais forças políticas do país, inclusive a eleição de um presidente oriundo de um partido de esquerda, mas torna muito alto o custo de processos de mudança legislativa, que aumentam ainda mais, quanto mais ampla e heterogênea for a coalizão de governo. Tanto o governo Fernando Henrique Cardoso, quanto o de Luís Inácio Lula da Silva podem ser assim caracterizados, mas o primeiro enfrentou menores problemas para obter apoio legislativo às suas propostas de políticas públicas do que o atual presidente.

Duas políticas governamentais têm sido mais insuladas do jogo legislativo: a política econômica e a política externa, mas por razóes diferentes. Tanto no governo Cardoso, quanto no governo Lula, a política macroeconômica contou com a clara delegação do presidente e de seus mandatários, que geralmente ocupam uma oposição de poder indiscutível na estrutura burocrática do governo. As medidas econômicas objeto de legislação específica são iniciadas pelo Executivo, que utiliza para sua aprovação seus amplos poderes de decreto. $\mathrm{O}$ insulamento burocrático da política externa tem outras causas. Ainda que esta não tenha o poder próprio e a autonomia, gozados pela política econômica, a política 
externa tem contado com a delegação das elites políticas em geral e do Congresso em particular, legitimidade atestada pela estabilidade do princípio constitucional da competência do Executivo na condução da política externa (Castro Neves, 2003). Esta delegação é fruto da percepção entre as forças políticas e sociais de que a política externa tem sido um instrumento de desenvolvimento importante, ou pelo menos assim o foi no período do modelo de substituição de importações. Neste sentido, a mudança do modelo de inserção internacional com a abertura econômica e as modificações decorrentes na política externa, em especial a adesão do Brasil aos novos regimes econômicos internacionais, de propriedade intelectual, serviços e outras sistemas normativos internacionais, tendem a erodir esta delegação prévia, na medida em que a internalização de novas normas e disciplinas internacionais inevitavelmente gera a politização interna da política externa.

Um outro fator que assegura grande autonomia decisória ao MRE é o desinteresse relativo da opinião pública em geral pelas questões de política externa. Um indicador deste desinteresse é a escassa disputa entre as forças partidárias com relação ao posto de Ministro das Relações Exteriores, confirmando o dito popular que política externa não dá votos (das dez nomeações para a chefia do MRE feitas entre 1985 e 2003, apenas três foram para políticos com filiação partidária). ${ }^{4}$ Os jornais brasileiros, com pouquíssimas exceções, dedicam um espaço pequeno à política externa. Mesmo questóes relevantes da agenda externa, como a postulação brasileira a um assento permanente nas Nações Unidas ou o envio recente de tropas brasileiras para uma missão de paz no Haiti, não mobilizam a opinião pública nem provocam os debates que normalmente ocorrem, por exemplo, no vizinho argentino.

Estas características institucionais da política externa, conjugadas com a natureza profissional da burocracia diplomática, que a aproxima do modelo do civil service clássico, têm garantido bastante autonomia na formulação da política externa e uma relativa continuidade das orientações da mesma. Este insulamento, porém, tende a ser disfuncional na medida em que a agenda externa se modifique com a introdução de novos temas e novos atores e a própria internalização dos acordos

\footnotetext{
${ }^{4}$ Ver Cesar (2002), citada em Amorim (2003).
} 
internacionais politizem a política externa. Estas transformações podem modificar este quadro de delegação/abdicação, que caracteriza sua base político-institucional doméstica. De modo geral, na visão da comunidade de política externa a avaliação da política exterior é bastante positiva. Contudo, aparece uma crítica velada ao insulamento diplomático no sentido de que o MRE não daria ao Congresso e às forças políticas e sociais a atenção necessária na formulação da política exterior (Souza 2002: 86-93). Este dado é um indicador de que a mudança de natureza da política exterior, em função de sua maior politização, possa induzir à modernização dos arranjos institucionais existentes, de modo a levar em conta os novos atores e interesses domésticos com orientação internacional.

No plano mais geral da agenda externa tradicional há um amplo consenso entre os operadores diplomáticos e as elites em geral na crença de que o país está destinado a ter um papel significativo na cena nacional e a expectativa do reconhecimento desta condição pelas grandes potências, em função de suas dimensões continentais, de suas riquezas naturais e da "liderança natural" entre os vizinhos (Souza, 2002: 19-21). A aspiração pelo reconhecimento internacional foi perseguida por via de uma presença ativa nos fóruns multilaterais desde a segunda metade do século XIX, quando surgiram os primeiros esforços de coordenação multilateral e, posteriormente, na constituição das Ligas das Nações, em que o Brasil empenhou-se em conseguir obter um assento permanente na organização (Garcia, 2000). Como ocorreu naquele momento e nos anos seguintes, o Brasil apresentou-se como mediador entre as grandes potências e as demais, posicionando-se na defesa dos direitos das potências menores e, simultaneamente, aspirando conquistar o status equivalente ao das grandes potências.

O fim do regime militar em 1985 e posteriormente o fim da Guerra Fria reacenderam nas elites brasileiras a aspiração de um papel influente na configuração da nova ordem no bojo do movimento de reforma das instituições internacionais. Em uma pesquisa de elites, realizada em 2001, a aspiração de transformar o Brasil em um ator relevante na política internacional é absolutamente consensual (Souza 2002: 3). O que estes e outros estudos sobre a opinião das elites revelam é que esta aspiração é constitutiva da própria identidade nacional, já que a percepção que as 
elites têm da identidade nacional constitui o substrato conceitual de sua projeção externa, "pautada principalmente no desejo de exercer um papel protagônico. Um território de proporções continentais, com dez vizinhos contíguos, grande população, uma economia diversificada e notável uniformidade cultural e lingüística são os diferenciais que conformam este sentimento de identidade, bem como essa expectativa de liderança" (Souza, 2002: 19; Lafer, 2001).

O consenso entre elites e a estabilidade desta expectativa de participação e liderança não impediram que o país seguisse modelos diferenciados de política externa que podem ser vistos como meios distintos para se obter o mesmo fim. De forma simplificada, poderiam ser identificadas duas estratégias internacionais seguidas pelo país a partir de meados do século XX: a de "bandwagoning” expressa na relação especial com os EUA e a de equilíbrio.

Os momentos em que a aliança especial guiou os passos da diplomacia foram vários, os mais significativos mencionados a seguir. No governo Vargas, a aliança política com os EUA durante a Segunda Guerra Mundial redundou na implantação da indústria siderúrgica no país e no reequipamento militar (1939-1942) (Moura, 1980). Durante a Guerra Fria, os militares e as elites conservadoras civis tinham naquele país um aliado importante para seus projetos de poder redundando no golpe militar de 1964. Mais recentemente, na fase de reestruturação do modelo de substituição das importaçóes, o alinhamento aos EUA funcionou como um avalista das mudanças econômicas iniciadas no governo Collor de Mello com a abertura comercial no início dos anos 90. Uma característica da aliança especial com os EUA foi seu sentido instrumental, como meio de concretização dos projetos domésticos das elites brasileiras e como instrumento equilibrador das rivalidades regionais, em particular com a Argentina.

O modelo do equilíbrio se caracteriza pela busca de alianças regionais e extra-regionais como mecanismos equilibradores de poder. A "diversificação da dependência" marcou diversos momentos da política externa no pós-Segunda Guerra. Nos anos 30, a "política de barganhas" do governo Vargas (1935-1937) expressou a idéia de buscar na Europa, uma parceria econômica e tecnológica alternativa (Moura, 1980). Algumas décadas depois, a "opção européia" foi posta em prática pelo governo 
militar do general Geisel na parceria com a então Alemanha Federal, para a aquisição do ciclo completo do combustível nuclear. Finalmente, em dois momentos da história recente, o modelo da autonomia/equilíbrio guiou os passos da política externa, na "política externa independente" (1961-1964) e no "pragmatismo responsável” (1970-1975). Uma das vertentes fortes do modelo autonomista foi o exercício de liderança nas questôes Norte-Sul tais como debatidas em arenas como o Gatt e a Unctad. A vertente de capacitação militar e em tecnologias sensíveis esteve presente apenas nos governos militares, culminando com a recusa brasileira em assinar o Tratado de Não-Proliferação Nuclear em 1968 e a assinatura do Acordo Nuclear com a Alemanha em 1975.

Naturalmente que as mudanças sistêmicas que culminam na década de 1990, com a consolidação da globalização produtiva e financeira e a configuração de uma ordem unipolar, por um lado e o processo de redemocratização com a posse de um governo civil em 1985 e a promulgação de uma nova constituição em 1988, por outro contribuíram para solapar as bases econômicas e políticas dos modelos prévios de política externa. Entre os fatores que se modificaram dois devem ser mencionados. Por um lado, observou-se a adesão brasileira aos regimes de direitos humanos e de controle de tecnologia sensível dos quais o país estivera afastado durante todo o regime militar. Por outro, o regionalismo e, em especial, as relações com a Argentina, a partir da criação do Mercosul em 1991, assumiram uma saliência e um significado totalmente distinto do padrão de afastamento/hostilidade que historicamente caracterizaram aquelas relações.

Curioso, porém, é que apesar de todas estas mudanças domésticas e internacionais tenha se mantido a aspiração das elites com relação ao papel protagônico do país, conforme demonstrado nas pesquisas sobre as opiniōes da comunidade brasileira de política externa. Mas tal como no passado, as elites se dividem quando se trata de escolher estratégias concretas de inserção internacional. Neste particular, dois modelos ressaltam nas preferências das elites, configurando-se duas alternativas de política externa, na atualidade. A primeira delas poderia ser denominada de busca da credibilidade, na medida em que o foco é de fora para dentro. A globalização é considerada o principal parâmetro para a ação externa e seus benefícios só podem ser alcançados pelas 
reformas internas que expandam a economia de mercado e promovam a concorrência internacional. Tal estratégia parte da constatação de que o país não possui "excedentes de poder" e, portanto, só o fortalecimento dos mecanismos multilaterais pode refrear "condutas unilaterais no cenário internacional". $\mathrm{Na}$ estratégia da credibilidade, a autonomia nacional "deriva da capacidade de cooperar para a criação de normas e instituições" internacionais (Souza, 2002: 22). Nesta percepção, o país deve ajustar seus compromissos internacionais às suas capacidade reais. A restauração da confiabilidade e da credibilidade internacionais está associada à vinculação da política externa à política econômica interna.

A estratégia oposta pode ser denominada de autonomista e combina o objetivo de projeção internacional com a permanência do maior grau de flexibilidade e liberdade da política externa. Crítica da avaliação positiva dos frutos da liberalização comercial e dos resultados benéficos da adesão aos regimes internacionais, esta visão preconiza uma "política ativa de desenvolvimento" e a necessidade de se "articular um projeto nacional voltado para a superação dos desequilíbrios internos em primeiro lugar". A inserção ativa deve ser buscada na "composição com países que tenham interesses semelhantes e se disponham a resistir às imposições das potências dominantes". A visão autonomista critica a tese da "insuficiência de poder" defendida pela estratégia da credibilidade, e a "postura defensiva" daí decorrente. Uma preocupação entre os defensores de uma estratégia autonomista é que o Brasil não dispóe de elementos de dissuasão militar, nem poder de veto no Conselho de Segurança da ONU que possam respaldar negociaçóes comerciais com parceiros mais poderosos. Como a dimensão soberanista é marcante nesta visão, prevalece certa relutância em aceitar arranjos multilaterais que impliquem delegação de autoridade a instâncias supranacionais (Souza, 2002: 23-25).

Estas duas estratégias de inserção internacional do Brasil, segundo as preferências da comunidade de política externa, guardam alguma semelhança com as orientações da política externa no período pós-Guerra Fria. Na prática, a gestão externa do governo Fernando Henrique Cardoso estaria mais próxima da estratégia de "credibilidade" e a de Luís Inácio Lula da Silva da de "autonomia". Contudo, no plano da diplomacia econômica multilateral, as orientações destes dois governos não são muito diferentes: a revitalização e ampliação do Mercosul; a intensificação da 
cooperação com a América do Sul e com os países africanos; "relações maduras" com os Estados Unidos; importância das relações bilaterais com potências regionais como China, Índia, Rússia e África do Sul; ampliação do número de membros permanentes no Conselho das Nações Unidas; participação nos principais exercícios multilaterais em curso - Rodada de Doha da Organização Mundial do Comércio, negociação da Alca e entre Mercosul e União Européia -, assim como na conformação das novas regras que irão reger as relações econômicas com vistas à defesa dos interesses dos países em desenvolvimento. Essa relativa estabilidade da agenda diplomática reflete tanto o peso da geografia nas relações internacionais dos países, quanto o efeito inercial da participação em longos processos de negociação econômica multilateral.

A principal diferença entre os dois governos é de perspectiva, da visão da ordem internacional de cada um deles. Ao buscar consolidar relações com a corrente principal da economia global - Estados Unidos, Europa e Japão -, repudiando assim as orientações terceiro-mundistas, um dos eixos do modelo autonomista pretérito, o governo Fernando Henrique Cardoso enfatizava uma determinada perspectiva da ordem mundial, representação esta, próxima ao que alguns analistas denominam o sistema geoeconômico de Clinton. Isto é, uma ordem em que a globalização é a tendência dominante, com o predomínio indiscutível dos Estados Unidos, com base na sua superioridade militar, econômica e tecnológica.

Tal como articulado no modelo da credibilidade, a restauração da confiabilidade internacional está associada tanto à adesão aos regimes internacionais dos quais o país esteve afastado durante o regime militar, quanto à adesão ao compromisso com a estabilização macroeconômica e a manutenção da governabilidade, de acordo com o léxico das agências financeiras e do mercado internacional. Tanto assim que a ortodoxia no plano macroeconômico foi acompanhada de uma política externa cujo principal vetor foi a participação ativa nos âmbitos multilaterais.

$\mathrm{O}$ entendimento da ordem internacional que transparece nos pronunciamentos e iniciativas do governo Lula é distinto. Ainda que reconhecendo o predomínio militar dos EUA, a avaliação da ordem econômica é mais matizada, em função da criação do euro que enfraqueceu o poder do dólar e, conseqüentemente, fortaleceu a União Européia. Em um mundo menos homogêneo e mais competitivo, haveria 
espaço para um movimento contra-hegemônico cujos eixos estariam na Europa ampliada, com a inclusão da Rússia e na Ásia, onde potências como China e Índia podem vir a representar um contraponto aos EUA na região.

Nessa percepção, a unipolaridade não consegue se legitimar, pois a tentação imperial é permanente o que, simultaneamente, estimula o investimento das demais potências em um esforço contra-hegemônico. Em um contexto mundial com vetores multipolares, o exercício multilateral, em particular nos fóruns políticos, torna-se crucial para atenuar a primazia norte-americana e conter seus impulsos unilaterais, que se tornariam inevitáveis em uma ordem internacional sem competidores ou opositores.

Ainda que seja cedo para uma avaliação da política externa do governo de Lula, sua característica distintiva com respeito ao anterior é combinar uma política macroeconômica ortodoxa, em tudo semelhante à de seu antecessor, e uma política externa heterodoxa muito próxima da estratégia autonomista articulada pela comunidade de política externa, como vimos anteriormente. Dada as injunçóes internacionais que o governo Lula experimenta, sua política externa parece constituir um dos domínios escolhidos para a reafirmação de seu compromisso com a mudança e com uma agenda social-democrata. No plano das ações diplomáticas, ressalta-se o forte componente de uma típica política de equilíbrio em relação à potência global com base em alianças com outras potências médias, dentro e fora do espaço regional sul-americano, como é o caso, por exemplo, da iniciativa IBSA.

De um ponto de vista analítico, a estratégia da credibilidade tem mais pontos de contato com a identidade de um mercado emergente, em oposição a da autonomia que se aproxima mais de uma de systemaffecting state. No governo Cardoso, as ações de política externa foram subsidiárias à prioridade conferida à manutenção da estabilidade e da credibilidade. No governo Lula, ao contrário, a política externa parece ter se desvinculado da ortodoxia macroeconômica em curso. O legado desenvolvimentista, conservado por algumas burocracias do Estado brasileiro, recuperou espaço na política externa deste governo. Mas ao contrário da estratégia autonomista do regime militar, a identidade de um país system-affecting e estratégia de equilíbrio, incluem, no contexto 
democrático atual, um forte viés de cooperação regional e a renúncia à dissuasão militar nuclear, dois ganhos obtidos com a promulgação da Constituição de 1988.

\section{Brasil e a regulação multilateral da segurança e do comércio internacionais}

Uma ativa presença e participação em arenas multilaterais têm sido uma constante na política externa brasileira desde o final do século XIX. Como o único país da América do Sul a participar da Primeira Guerra Mundial, na qualidade de país beligerante, o Brasil garantiu presença na Conferência de Paz em 1919. Data desta época, as primeiras iniciativas brasileiras para a reforma do ainda incipiente regime de segurança coletiva representado pela criação da Liga das Nações. Naquela ocasião, o Brasil apresentou-se como mediador entre as grandes potências e as demais, posicionando-se na defesa dos direitos das potências menores e, simultaneamente, aspirando conquistar o status equivalente ao das grandes potências (Garcia, 2000; e Mello e Silva, 1998).

O Brasil também esteve presente nas principais conferências que instituíram a estrutura de governança da ordem pós-1945. Foi membro fundador das Naçōes Unidas, um dos 23 "pais fundadores" do Gatt e um dos 56 países representados nas negociações da ITO (Organização de Comércio Internacional) em Havana (Abreu, 1999). De modo geral, a participação de países como a Índia e o Brasil nas instituições de regulação da ordem pós-45 foi pautada pelos objetivos de desenvolvimento econômico e autonomia política. Nos anos 60 e 70, o ativismo político no âmbito da coalizão do Terceiro Mundo concentrou-se, para o Brasil, nas questôes econômicas, em particular na Unctad e no Gatt, e para a Índia nas de natureza política a partir do Movimento dos Não-Alinhados (Sennes, 2001). Da perspectiva da diplomacia brasileira, apenas nas questôes Norte-Sul haveria espaço para a invenção diplomática e coordenação da ação política da coalizão desenvolvimentista, ao contrário das de LesteOeste em que o trabalho diplomático se resumiria à reação a crises "que não criamos" (Fonseca Jr., 2000: 308).

O foro político das Nações Unidas também foi um espaço para demandas de reforma, observando-se uma convergência entre os dois 
países em torno do tema da "democratização" do processo decisório. $\mathrm{Na}$ visão brasileira, as Nações Unidas não deveriam ater-se apenas às questôes de paz e de segurança, mas ampliar seus horizontes de modo a incluir o bem estar e o progresso da comunidade das nações (Sardenberg, 2000). Nos anos 60, a convergência Brasil e Índia foi máxima por ocasião das discussões, no Comitê de Desarmamento, quando das negociações do Tratado de Não-Proliferação (TNP). Ambos países apoiavam as medidas de desarmamento, mas se recusaram a assinar o tratado e as razões apresentadas foram bastante semelhantes. Para o Brasil, o TNP configurava-se na expressão máxima do "congelamento do poder mundial", enquanto para a Índia era um instrumento de "nãoproliferação da ciência e tecnologia”. Contudo, o ponto de vista indiano tendia a enfatizar os aspectos relacionados à segurança e o brasileiro às questôes econômicas e tecnológicas. (Lima, 1986: 77-90).

Entre os membros não-permanentes, Brasil e Índia foram os países que ocuparam por mais tempo, uma vaga no Conselho de Segurança, 14 anos não consecutivos para o Brasil e 12 para a Índia, no período entre 1945 e 1996. (Sennes, 2001: 96). Contudo, o Brasil esteve ausente do Conselho por vinte anos, entre 1968 e 1988. A primeira data coincidiu com a recusa brasileira em aderir ao TNP e a segunda marcou o retorno pleno da democracia no país. Desta forma, a coincidência fortuita entre o fim da Guerra Fria e o fim do regime militar brasileiro relançaram um novo ciclo da participação brasileira nas discussóes sobre a reforma de um dos principais pilares do sistema de segurança coletiva da ordem de 45 .

As preocupações brasileiras com relação à agenda da reforma concentram-se em torno de três grandes eixos que, de resto, refletem posturas tradicionais brasileiras: o reforço dos princípios multilaterais, em particular nos casos de autorização do uso dos instrumentos coercitivos, previstos no capítulo VII da Carta das Nações Unidas; soluções inovadoras que possam restabelecer a fronteira conceitual e operacional entre os mecanismos de manutenção da paz e os de peace enforcing; e reforma da estrutura decisória do Conselho de modo a dotá-lo de representatividade e legitimidade na nova ordem pós-Guerra Fria. (Amorim, 1999; Herz, 1999; Sardenberg, 2000).

A ênfase no multilateralismo espelha a própria identidade internacional do país, que vê na mediação entre os fortes e fracos 
sua principal contribuição para a estabilidade internacional e o reconhecimento de sua projeção internacional não pelo recurso à força, mas pela diplomacia parlamentar. (Lafer, 2001). Para o Brasil, o fortalecimento do arcabouço jurídico-parlamentar do sistema da ONU se tornou ainda mais necessário na nova ordem unipolar que emergiu com o desaparecimento da União Soviética. Um enfraquecimento do Conselho de Segurança seja por paralisia decisória, como no período da Guerra Fria, seja por ficar a serviço das açōes unilaterais dos EUA seria desastroso para o Brasil. Nas palavras do embaixador Celso Amorim, "a proteção da credibilidade do Conselho de Segurança pode ser vista como um verdadeiro objetivo nacional". (Amorim, 1999: 93).

A distinção conceitual entre as operações de paz e as de peace enforcement das ações coercitivas sob o capítulo VII remete a três pilares básicos da política externa: a defesa do princípio da não-intervenção, da norma da solução pacífica das controvérsias e das raízes econômicas das questões de segurança. A preocupação brasileira centra-se na multiplicação dos regimes de sançóes e na necessidade de regulá-los de forma a adicionar à noção de "diplomacia preventiva" medidas de cooperação internacional para o desenvolvimento, além das ações mediadoras usuais, não coercitivas.

Finalmente, a reforma da estrutura decisória do Conselho está referida à tese da "democratização" do processo decisório, também cara à comunidade de política externa. A candidatura brasileira a um assento permanente no Conselho de Segurança foi anunciada oficialmente pelo então chanceler Celso Amorim em 1994, no âmbito do lançamento do projeto de reforma do Conselho naquele mesmo ano. A ampliação do Conselho é justificada pela necessidade de adequar o organismo às novas realidades do mundo pós-Guerra Fria e deverá ser guiada por critérios que impliquem em um aumento da representatividade e da equidade do órgão com vistas a ampliar sua legitimidade e eficácia. (Mello e Silva, 1998). Para o Brasil, a legitimidade do Conselho depende da ampliação de sua representatividade política, de forma a adequar a estrutura decisória do órgão às realidades políticas do atual sistema internacional.

África do Sul, Índia e Brasil reivindicam a posição de membros permanentes com base no princípio de representatividade geográfica. México e Argentina têm posiçôes distintas, já que defendem a ampliação 
do número de membros não permanentes. Desde então, dada a quase impossibilidade de se articular uma posição regional comum, o tema foi abordado em contatos bilaterais, fora da América Latina, com países que também já manifestaram simpatia ou interesse nesta ampliação tais como França, Alemanha, China, Índia e África do Sul. Mais recentemente, o governo Lula incluiu este tema entre as prioridades de sua agenda de política externa. Desta feita, o tema foi abordado também em conversações com países sul-americanos, no bojo da ênfase que este governo conferiu às relações com a região sul-americana. A iniciativa IBSA tem na questão da reforma do Conselho um de seus pontos programáticos. Mas dada a sensibilidade que o tema provoca nas relaçóes com a Argentina, coloca-se um conflito potencial entre a postulação brasileira e o aprofundamento das relações do Brasil com os países sul-americanos.

A centralidade desta questão na agenda externa do governo Lula e o aprofundamento do comportamento crescentemente unilateral do governo Bush, na implementação da "guerra ao terror" no pós 11 de Setembro, provocaram uma atenuação de algumas reservas prévias brasileiras com relação a um compromisso mais profundo com as atividades de manutenção da paz do sistema ONU. Ainda que, ao longo dos anos, o país tenha contribuído em diversas missōes desta natureza, comparando-se com a Argentina, sua participação em termos do tamanho do contingente enviado e da localização geográfica da missão foi sempre menor e geralmente focalizada em regiōes com prévios vínculos políticos e culturais, como por exemplo, os países africanos de língua portuguesa, o Timor Leste, de colonização portuguesa, e países latino-americanos. O comando brasileiro de uma força de paz de cerca de mil e duzentos soldados no Haiti, a partir de junho de 2004, não apenas demonstra uma nova postulação com respeito ao exercício de um papel mais intervencionista em face de situações de conflito interno e/ou guerra civil, que possam reverberar em seu perímetro de segurança, como se dá em um país do Caribe, região com fracos vínculos com o Brasil. Nos anos 90, por exemplo, o Brasil absteve-se de apoiar, no âmbito do Conselho de Segurança, o envio de uma missão multinacional àquele país, posição acompanhada pela República Popular da China.

Ao contrário das questóes de paz e segurança em que o Brasil não teve uma participação continuada na ordem de 1945 e praticamente só 
no pós-Guerra Fria assumiria uma postura protagônica, nas negociações da reforma do regime de comércio e de desenvolvimento a participação brasileira tem sido constante e ativa desde sua implantação em meados do século XX. Juntamente com países como a Índia e o México, o Brasil teve papel destacado na coordenação da coalizão terceiro-mundista, tendo liderado o G-77 nos anos 60. As questões de interesse destes países diziam respeito basicamente à constituição de um sistema de comércio e desenvolvimento que, levando em conta os interesses específicos daquele conjunto de economias, instituísse mecanismos especiais para fazer face à situação de desigualdade entre os países no sistema de comércio global. As reformas eram defendidas em nome da observância de um princípio de justiça distributiva, princípio este que um sistema liberal seria impermeável: desiguais não podem ser tratados como iguais. Em certo sentido, o custo da liderança da "coalizão dos fracos" era suportado, quase que exclusivamente, pelos grandes países em desenvolvimento que haviam adotado estratégias de crescimento para dentro. Da mesma forma, as pequenas economias exportadoras do sudeste asiático, os NICs dos anos 70, eram os caronas deste esforço de liderança dos países em desenvolvimento, uma vez que foram amplamente beneficiados por alguns dos mecanismos introduzidos no regime de comércio, como o SGP, por exemplo. (Lima, 1986).

Entre as décadas de 1960 e o início da de 1980, não sendo ainda um demandeur no regime de comércio, a participação brasileira centrava-se na defesa de certos princípios e praticamente não negociava questôes específicas:

- preferência por um regime de comércio baseado nos princípios de cooperação e desenvolvimento (Unctad) em oposição aos princípios de mercados livres (Gatt);

- forte apoio ao fortalecimento de normas comerciais tais como a de "não-discriminação" e a de "nação mais-favorecida", que garantissem menor arbitrariedade e impedissem comportamentos unilaterais e medidas protecionistas da parte dos países desenvolvidos;

- forte apoio à implantação de normas diferenciadas favorecendo os países em desenvolvimento, tais como a de "tratamento especial e diferenciado" e de "não-reciprocidade"; 
- alinhamento político com o G 77 em outras arenas multilaterais. $^{5}$

A partir dos anos 80, a postura brasileira foi de limitação de danos, isto é, retardar ou mesmo impedir a instituição de normas e procedimentos que: (a) diferenciassem os países em desenvolvimento; (b) enfraquecessem as normas multilaterais; e (c) ampliassem as matérias e questôes substantivas sujeitas à disciplina normativa do regime de comércio. Desta forma, na Rodada de Tóquio um dos principais objetivos brasileiros foi impedir a introdução de medidas de "graduação" reservadas aos mais desenvolvidos entre os países em desenvolvimento. Outro objetivo negociador prioritário foi fortalecer o sistema multilateral, em especial a norma da Nação Mais Favorecida (MFN) no caso da instituição dos diversos Códigos Não-Tarifários (NTB), alguns de grande interesse para o Brasil como os de Anti-Dumping; Subsídios e Medidas Compensatórias; e Salvaguardas. (Lima, 1986).

Entre o final da Rodada de Tóquio e o início da Rodada Uruguai, o Brasil e a Índia vão cooperar ativamente no G-10 face à iniciativa norteamericana de ampliar a agenda da Rodada com a introdução de novas questôes (propriedade intelectual, serviços e investimentos) a serem objeto de regulação internacional. A partir da Rodada do Uruguai, vão ficar claros os limites negociadores de uma estratégia de limitação de danos calcada no duplo objetivo de impedir a dissolução do regime de comércio multilateral e fortalecer as normas multilaterais que dificultem comportamentos unilaterais e, simultaneamente, evitar o isolamento político, no interior da "coalizão dos fracos" que enfraqueceria a participação destes dois países em uma eventual cooperação com os países desenvolvidos. ${ }^{6}$

$\mathrm{Na}$ Rodada Uruguai, não apenas a agenda negociadora se torna mais ampla e mais complexa, como se modifica a própria estrutura do processo negociador. Levando-se em conta os interesses negociadores brasileiros, as principais modificações foram:

\footnotetext{
${ }^{5}$ Uma discussão aprofundada destas características do regime comercial nas décadas de 1960 a 1980 é efetuada por SENNES, 2001, p. 157. Para uma análise histórica da participação brasileira no Gatt, ver ABREU, 1996).

${ }^{6}$ Ver a discussão dos limites desta estratégia em SENNES, 2001: 130-173. De acordo com ABREU, 1999, o Grupo dos 10 estava reduzido, de fato, a dois parceiros, Índia e Brasil.
} 
- mudança na estrutura das negociações, uma vez que estas últimas vão além das medidas de fronteira clássicas (agenda negativa e concessões mútuas tarifárias), implicando em compromissos ativos de políticas governamentais com repercussões domésticas;

- configuração de novas coalizões envolvendo países em desenvolvimento e países desenvolvidos, como a formação do Grupo de Cairns.

- Crise do G-77 e divisão política entre os países em desenvolvimento: o G-10, liderado pela Índia, o Brasil e o Egito, bloqueando a introdução de novas questões e disciplinas normativas e concentrando-se na agenda tradicional do Gatt, versus o G-20, com a participação de países desenvolvidos e em desenvolvimento, mais favorável a aceitar o trade off entre a velha e a nova agenda. (Sennes, 2001:174-214).

A partir de 1988, os países em desenvolvimento vão flexibilizar suas posições negociadoras no contexto da crise de seus modelos de desenvolvimento prévio. Esta pulverização política do G-77 e o efeito bandwagoning, que então se observa representam o limite das antigas posturas de princípio defendidas no passado. A partir de então, as coalizões terão que ter como solda não apenas princípios, mas também interesses concretos.

Em certa medida, o G-20 que se forma na reunião de Cancun, no México, em 2003, representa um renascimento da coalizão terceiro-mundista agora, porém, em torno dos interesses agrícolas dos países em desenvolvimento e na explicitação da hipocrisia da posição negociadora dos países desenvolvidos. Para o Brasil, a criação do G-20, retomando a coordenação com a Índia, é uma oportunidade de mais uma vez desempenhar o papel de "intermediário indispensável” entre os "fracos" e os "fortes". Por outro lado, a novidade para o Brasil, na negociação de Doha é ser um demandeur na questão agrícola em função da alta competitividade das exportações agrícolas brasileiras, além da manutenção de sua agenda negociadora tradicional, centrada no acesso a mercados e fortalecimento das normas multilaterais. (Abreu, 1999). A formação do G-20 e a nova situação de demandeur na área agrícola representam o retorno brasileiro aos dois tabuleiros de atuação diplomática: o da cooperação Sul-Sul e o da negociação de concessões 
comerciais com os principais parceiros do Norte. Cabe mencionar que a liberalização do comércio agrícola é do máximo interesse brasileiro, em vista da alta competitividade deste setor, o que não é necessariamente o caso dos demais participantes do G-20, mas estão todos unidos diante da insatisfação com a estratégia da União Européia e dos Estados Unidos de protelarem uma liberalização radical de seus setores agrícolas e insistirem na liberalização de outros setores de seu interesse.

A dinâmica da arquitetura negociadora das reformas de governança, tanto das questôes de paz e segurança, quanto das de comércio e desenvolvimento sugere que, na atualidade, países como a África do Sul, o Brasil e a Índia enfrentam um dilema de difícil solução. Ao contrário da ordem pós-45 quando a construção de um sistema multilateral foi obra das potências, leia-se os EUA, no pós-Guerra Fria a oferta de um sistema multilateral de segurança e de comércio parece depender mais das iniciativas dos países mais desenvolvidos, entre os em desenvolvimento. Contudo os paises intermediários não contam mais com a totalidade do apoio da "coalizão dos fracos" em função do efeito bandwagoning acima mencionado. Por outro lado, os países desenvolvidos parecem não depender tanto do arcabouço multilateral, na medida em que dispõem de outros mecanismos, sejam bilaterais, minilaterais, regionais, e mesmo unilaterais, para defender seus interesses nas questôes de comércio e de segurança. Este não é o caso dos três mencionados, para os quais a opção multilateral ainda é superior às demais. Desta forma, a opção de saída é muito mais custosa para eles do que para os países desenvolvidos. $\mathrm{O}$ grande desafio para África do Sul, Brasil e Índia é como exercer a opção de voz, sem perder efetividade, e buscar trade offs melhores nas questôes de seus interesses sem provocar o enfraquecimento ou mesmo a destruição dos regimes de comércio e de segurança coletiva.

Diante deste dilema, a posição do atual governo parece ser de manter a presença nos dois tabuleiros. O G-20 é visto pela diplomacia como uma coalizão pragmática que expressa o reconhecimento de que hoje o "que ocorre nos grandes países em desenvolvimento, como China, Índia e Brasil, impacta cada vez mais no mundo industrial”. ${ }^{7}$ Dentro da comunidade de política externa, porém, estas questões não

\footnotetext{
${ }^{7}$ Ver entrevista do Ministro das Relaçōes Exteriores: Celso Amorim: G-8 necessita del Sur si quiere legitimar-se, Inter Press Service Agency, disponível em: < http://ipsnoticias.net>.
} 
são consensuais. Para alguns, o Brasil deveria concentra-se na sua agenda de demandeur do setor agrícola e nas questôes da sua agenda tradicional e evitar a repetição de práticas obstrucionistas do passado. ${ }^{8}$ Por outro lado, há consenso total com relação à prioridade das negociações no âmbito da OMC. Para alguns, é nesta arena que o Brasil tem condições de obter ganhos melhores do que em negociações como a da Alca ou do Mercosul-União Européia, por exemplo. ${ }^{9}$

As questões de paz e segurança não provocam a mesma mobilização que as de comercio e o debate interno é quase inexistente. Contudo, entre os setores mais nacionalistas existe o temor que o custo do trade off, envolvido na questão da candidatura brasileira ao Conselho de Segurança, em termos de uma participação mais sistemática e de envergadura nas missões de paz, talvez seja muito alto. Não apenas por violar o princípio da soberania, mas por representar uma situação em que o país estaria antes colaborando com a agenda de segurança do governo Bush, do que propriamente com a de segurança coletiva das Nações Unidas.

\section{As bases domésticas para a ampliação da cooperação econômica e política}

De uma perspectiva histórica, a geografia e legados políticos específicos dificultaram vínculos políticos e econômicos mais estreitos entre os três países, apesar de semelhanças estruturais relevantes entre eles. Os três podem ser classificados como membros semiperiféricos do sistema econômico mundial; são poderosos regionais; ricos em recursos naturais; nível razoável de industrialização e população multiétnica. São grandes democracias de massas com gravíssimos problemas de inclusão social. No caso brasileiro, esta combinação perversa tem sido atenuada pela profundidade da inclusão eleitoral que tornou possível que o país, apesar do conservadorismo de suas elites dirigentes, tenha elegido um ex-metalúrgico presidente da República.

\footnotetext{
${ }^{8}$ Ver: ABREU, Marcelo, Riscos da nova estratégia brasileira na OMC. O Estado de São Paulo, $1^{\circ}$ de set./2004; e ABREU, Marcelo de Paiva. A raposa e o porco-espinho: negociações comerciais não devem perder de vista a grande estratégia do Brasil. O Estado de São Paulo, 29 de set/ 2003.

${ }^{9}$ Ver, BATISTA, Paulo Nogueira Jr. Réquiem para o acordo Mercosul-União Européia?. Folha de São Paulo, 17 de jun/04.
} 
A tabela 2 sugere algumas particularidades entre eles. Do ponto de vista dos indicadores sociais, o Brasil apresenta um desempenho melhor que os demais e é um país majoritariamente urbano. O dado desabonador é a extrema desigualdade que faz com que o país exiba o maior valor do índice Gini, comparado aos demais. A Índia é um país majoritariamente rural, com uma população imensa e relativamente mais pobre que as demais; tanto sua renda per capita, como os valores de seu Índice de Desenvolvimento Humano (IDH) são inferiores aos dos demais. Finalmente, a África do Sul estaria colocada entre os dois, no que diz respeito aos indicadores sociais, mas com uma expectativa de vida bem mais baixa que a dos outros dois, em função do gravíssimo problema de saúde representado pela incidência da Aids no país. Um dado alvissareiro é a maior porcentagem de mulheres em cargos políticos, reflexo da ativa política de ação afirmativa levada a cabo pelos governos pós-apartheid.

\section{Tabela 2}

Indicadores Econômicos, Sociais e Políticos Básicos

Brasil-Índia-África do Sul

\begin{tabular}{l|r|r|r}
\hline & Brasil & Índia & $\begin{array}{r}\text { África } \\
\text { do Sul }\end{array}$ \\
\hline Área (km²) (milhões) & 8,547 & 3,287 & 1,223 \\
População Total (milhões), 2001 & 174,0 & $1.033,4$ & 44,4 \\
Taxa de crescimento anual população (\%), 1975-2001 & 1,8 & 2,0 & 2,1 \\
População urbana (como \% do total), 2001 & 81,7 & 27,9 & 57,6 \\
PIB (US\$ bilhões), 2001 & 502,5 & 477,3 & 113,3 \\
PIB per capita (US\$), 2001 & 2,915 & 462 & 2,620 \\
PIB per capita (PPP US\$), 2001 & 7,360 & 2,840 & 11,290 \\
PIB per capita taxa de crescimento anual (\%), 1990-2001 & 1,4 & 4,0 & 0,2 \\
Exportações de manufaturados (como \% das exportações de mercadorias), 2001 & 54 & 77 & 59 \\
Serviço da dívida total (como \% das exportações de bens e serviços), 2001 & 28,6 & 12,6 & 6,8 \\
Gastos públicos em educação (como \% do PIB), 1998-2000 & 4,7 & 4,1 & 5,5 \\
Gastos públicos em saúde (como \% do PIB), 2000 & 3,4 & 0,9 & 3,7 \\
Gastos militares (como \% do PIB), 2001 & 1,5 & 2,5 & 1,6 \\
Expectativa de vida ao nascer (anos), 2000-2005 & 68,1 & 63,9 & 47,7 \\
Taxa de mortalidade infantil (por 1.000 nascimentos), 2001 & 31 & 67 & 56 \\
Taxa de alfabetização de adultos (\% 15 anos e acima), 2001 & 87,3 & 58,0 & 85,6 \\
Índice de desenvolvimento humano (HDI) valor, 2001 & 0,777 & 0,590 & 0,684 \\
Ordenamento & 65 & 127 & 111 \\
Índice Gini & 60,7 & 37,8 & 59,3 \\
Ano que mulheres receberam direito ao voto & 1934 & 1950 & 1930,1994 \\
Cadeiras no parlamento ocupadas por mulheres (como \% do total) & 9,1 & 9,3 & 30,0 \\
\hline Fonte: Human Deve
\end{tabular}

Fonte: Human Development Reports, 2003, UNDP. 
No Brasil, tal como nos demais, os problemas crônicos de desigualdade de renda, analfabetismo e pobreza se agudizaram na década de 1990, em função da crise do modelo desenvolvimentista e do ajuste estrutural por que passou sua economia. Conjugar o crescimento auto-sustentado com o atendimento das demandas sociais reprimidas é a difícil equação que o atual governo tenta solucionar. A cooperação Sul-Sul é concebida no atual governo como um dos instrumentos no equacionamento deste desafio.

Do ponto de vista brasileiro, a Iniciativa IBSA não visa apenas a cooperação no âmbito multilateral nas questões de paz e segurança, por um lado e comércio e desenvolvimento, por outro, mas objetiva também construir vínculos políticos e econômicos fortes entre os três países. Historicamente e por razões diferentes, estes vínculos não foram estreitos, quer no plano econômico, quer no político.

A distribuição geográfica do comércio exterior brasileiro vem se modificando desde a década de 1970, mas ainda mantém o padrão centro-periferia clássico. Como se pode observar na tabela 3, os países industrializados ainda constituem o principal destino e origem deste comércio, ainda que ao longo do tempo, a América Latina tenha se tornado uma das três principais áreas de concentração do comércio. No caso dos investimentos, este padrão é ainda mais acentuado, na medida em que os Estados Unidos, a Alemanha e o Japão são os países com os maiores estoques de investimento no Brasil, sendo responsáveis por mais da metade do capital estrangeiro aplicado no país. O movimento de internacionalização dos investimentos brasileiros no exterior, que adquiriu maior significado no início da década de 1990, privilegiou a América do Sul, particularmente a Argentina, os paraísos fiscais, a América do Norte e a Europa. (Pinheiro e Castelar, p. 14-17). 
Tabela 3

Distribuição Geográfica do Comércio Exterior brasileiro

(1970-1995, em \%)

\begin{tabular}{l|c|c|c|c|c|c|c|c}
\hline & \multicolumn{5}{|c|}{ Exportações } & \multicolumn{3}{c}{ Importações } \\
\cline { 2 - 9 } & 1970 & 1980 & 1990 & 1995 & 1970 & 1980 & 1990 & 1995 \\
\hline Industrializados & 76,85 & 52,91 & 68,07 & 56,17 & 76,98 & 46,56 & 55,04 & 59,87 \\
EUA & 24,69 & 17,37 & 24,62 & 18,92 & 32,27 & 18,54 & 19,84 & 21,08 \\
Japão & 5,29 & 6,12 & 7,48 & 6,67 & 6,25 & 4,78 & 7,10 & 6,61 \\
União Européia & 34,93 & 27,15 & 33,68 & 27,07 & 28,56 & 15,38 & 22,50 & 26,70 \\
Países em Desenvolvimento & 23,15 & 41,59 & 30,42 & 42,86 & 20,95 & 53,44 & 44,46 & 39,34 \\
África & 2,20 & 6,52 & 2,44 & 2,51 & 3,31 & 4,70 & 2,85 & 2,49 \\
América Latina & 11,74 & 20,46 & 11,57 & 23,09 & 12,02 & 12,52 & 17,14 & 20,54 \\
África do Sul & 0,60 & 0,51 & 0,53 & 0,56 & 0,08 & 0,91 & 0,40 & 0,67 \\
Outros & 0,00 & 5,50 & 1,51 & 0,97 & 2,06 & 0,00 & 0,50 & 0,79 \\
Total & 100,00 & 100,00 & 100,00 & 100,00 & 100,00 & 100,00 & 100,00 & 100,00 \\
\hline
\end{tabular}

Fonte: FMI. Apud: Pinheiro e Moreira, 1996, p. 336.

Diante deste quadro, é compreensível a relativa e pouco expressiva participação da Índia e da África do Sul no comércio exterior brasileiro, até bem recentemente. Conforme pode ser visualizado na tabela 4, o comércio bilateral com os dois países ficou, quase sempre, abaixo de $1 \%$ na totalidade das trocas comerciais brasileiras. $\mathrm{O}$ dado significativo é que a partir de 2001, observa-se um aumento expressivo no valor das trocas comerciais tanto com a Índia, quanto com a África do Sul. Em valores, no caso da Índia, passando de US\$ 488 milhões em 2000 para US\$ 1.039 bilhões em 2003 e, no caso da África do Sul de US\$ 529 milhōes para US\$ 935 milhões, no mesmo período. No caso da Índia, este aumento, excepcional para o padrão histórico do comércio bilateral, se deveu ao aumento conjunto da participação indiana nas importaçôes e exportações brasileiras no período. Com relação à África do Sul, aumentaram significativamente as exportações brasileiras para este país, de modo tal que o último passou da $27^{\circ}$ posição no ranking dos principais mercados de destino das exportações brasileiras, para a $19^{\circ}$ posição entre 2002 e 2003, uma variação de 53,5\%. (ver tabela 5). No mesmo período, as exportações para Índia passaram de US\$ 653 milhões para US\$ 553 milhôes. A tabela 5 demonstra a nova importância do mercado chinês para as exportações brasileiras, passando aquele país a ocupar o terceiro lugar nas exportaçóes brasileiras, abaixo dos EUA e da Argentina, dois destinos tradicionais de nossas vendas externas. 


\section{Tabela 4}

Comércio Bilateral entre Brasil e Índia e África do Sul

(1989-2004, em US\$ milhões)

\begin{tabular}{c|c|c|c|c}
\hline Ano & $\begin{array}{c}\text { Total do Comércio } \\
\text { Bilateral com África } \\
\text { do Sul }\end{array}$ & $\begin{array}{c}\text { Comércio Exterior } \\
\text { Brasileiro }\end{array}$ & $\begin{array}{c}\text { Total do Comércio } \\
\text { Bilateral com } \\
\text { a Índia }\end{array}$ & $\begin{array}{c}\% \\
\text { Comércio Exterior } \\
\text { Brasileiro }\end{array}$ \\
\hline 1989 & 256,044 & 0,5 & 233,932 & 0,4 \\
1990 & 246,766 & 0,5 & 183,996 & 0,4 \\
1991 & 236,269 & 0,4 & 198,274 & 0,4 \\
1992 & 267,623 & 0,5 & 148,699 & 0,3 \\
1993 & 324,815 & 0,5 & 215,945 & 0,3 \\
1994 & 467,569 & 0,6 & 709,200 & 0,9 \\
1995 & 597,869 & 0,6 & 487,794 & 0,5 \\
1996 & 710,297 & 0,7 & 370,686 & 0,4 \\
1997 & 683,054 & 0,6 & 382,449 & 0,3 \\
1998 & 507,069 & 0,5 & 356,555 & 0,3 \\
1999 & 409,604 & 0,4 & 483,941 & 0,5 \\
2000 & 529,897 & 0,5 & 488,726 & 0,4 \\
2001 & 709,811 & 0,6 & 828,083 & 0,7 \\
2002 & 629,350 & 0,6 & $1.226,782$ & 1,1 \\
2003 & 935,381 & 0,8 & $1.039,015$ & 0,9 \\
$2004 *$ & 330,810 & - & 196,831 & - \\
\hline Total & $7.842,233$ & 0,5 & $7.550,914$ & 0,4 \\
\hline
\end{tabular}

Fonte: SECEX/Aliceweb.

* Período: Janeiro/2004 até abril/2004.

A despeito do aumento das exportaçōes brasileiras para a África do Sul, o país ainda não ocupa uma posição de destaque como destino dos investimentos brasileiros no exterior, totalizando cerca de US\$ $40 \mathrm{mil}$, em junho de 1995, segundo dados do Banco Central. Contudo, a presença de capitais sul-africanos no Brasil data dos anos 70, com o estabelecimento da companhia Anglo American no país. Os investimentos em mineração foram a porta de entrada para a expansão da empresa para outros países latinos, bem como para a diversificação de suas atividades no Brasil. Em julho de 1996 a empresa tinha investido no país US\$ 1 bilhão. (Pinheiro e Castelar, p. 20 e 25). 
Tabela 5

Principais destinos das exportações brasileiras

(2002-2003, em US\$ milhões)

\begin{tabular}{|c|c|c|c|c|c|c|c|}
\hline \multirow{2}{*}{\multicolumn{3}{|c|}{$\begin{array}{l}\text { Total das Exportações Brasileira } \\
22003\end{array}$}} & & 2003 & \multicolumn{2}{|c|}{2002} & r. \% \\
\hline & & & \multicolumn{2}{|r|}{73.084} & \multicolumn{2}{|c|}{60.362} & 1,1 \\
\hline \multicolumn{2}{|c|}{ Ranking } & Destino & 2003 & $\begin{array}{c}\text { \% comércio } \\
\text { total }\end{array}$ & 2002 & $\%$ comércio & Var. \% \\
\hline 2002 & 2003 & & & & & & \\
\hline 1 & 1 & Estados Unidos & 16.692 & 23 & 15.354 & 25 & 8,7 \\
\hline 6 & 2 & Argentina & 4.561 & 6 & 2.342 & 4 & 94,8 \\
\hline 4 & 3 & China & 4.533 & 6 & 2.520 & 4 & 79,8 \\
\hline 2 & 4 & Holanda & 4.246 & 6 & 3.182 & 5 & 33,4 \\
\hline 3 & 5 & Alemanha & 3.136 & 4 & 2.537 & 4 & 23,6 \\
\hline 5 & 6 & México & 2.741 & 4 & 2.342 & 4 & 17,0 \\
\hline 7 & 7 & Japão & 2.311 & 3 & 2.098 & 3 & 10,1 \\
\hline 9 & 8 & Itália & 2.208 & 3 & 1.817 & 3 & 21,5 \\
\hline 10 & 9 & Reino Unido & 1.899 & 3 & 1.769 & 3 & 7,3 \\
\hline 12 & 10 & Chile & 1.880 & 2 & 1.461 & 2 & 28,7 \\
\hline 8 & 11 & Bélgica & 1.795 & 2 & 1.892 & 3 & $-5,1$ \\
\hline 11 & 12 & França & 1.715 & 2 & 1.525 & 3 & 12,5 \\
\hline 14 & 13 & Espanha & 1.552 & 2 & 1.120 & 2 & 38,5 \\
\hline 13 & 14 & Rússia & 1.500 & 1 & 1.252 & 2 & 19,8 \\
\hline 15 & 15 & Coréia do sul & 1.223 & 1 & 852 & 1 & 43,5 \\
\hline 17 & 16 & Canadá & 978 & 1 & 782 & 1 & 25,1 \\
\hline 26 & 17 & Irã & 869 & 1 & 492 & 1 & 76,8 \\
\hline 20 & 18 & Colômbia & 749 & 1 & 637 & 1 & 17,6 \\
\hline 27 & 19 & África do Sul & 733 & 1 & 478 & 1 & 53,5 \\
\hline 22 & 20 & Paraguai & 707 & 1 & 558 & 1 & 26,6 \\
\hline 24 & 21 & Hong Kong & 694 & 1 & 527 & 1 & 31,8 \\
\hline 31 & 22 & Taiwan & 989 & 1 & 430 & 1 & 60,1 \\
\hline 23 & 23 & Arábia Saudita & 673 & 1 & 558 & 1 & 20,5 \\
\hline 21 & 24 & Portugal & 628 & 1 & 582 & 1 & 8,0 \\
\hline 16 & 25 & Venezuela & 606 & 1 & 797 & 1 & $-24,0$ \\
\hline & & Outros Países & 13.767 & 19 & 12.458 & 21 & 10,51 \\
\hline
\end{tabular}

Fonte: SECEX. Elaboração: AEB 
$\mathrm{Na}$ dimensão política, as relações diplomáticas com ambos países foram estabelecidas em 1947/1948, mas só mais recentemente adquiriram maior expressão. No caso da Índia observou-se uma descontinuidade entre uma ativa colaboração no plano multilateral, quer no regime de segurança, quer no de comércio, e a pouca relevância das relaçóes econômicas e políticas bilaterais. Já com a África do Sul, foram basicamente fatores políticos que afastaram durante longo tempo os dois países. Desta forma, a estreita relação com Portugal e o conseqüente apoio ao colonialismo português, no âmbito das Nações Unidas e o regime sul-africano do apartheid acabaram por gerar um comportamento bastante ambíguo da diplomacia brasileira. Assim sendo, duas datas foram cruciais na construção destas relações. Em primeiro lugar, a Revolução dos Cravos e o fim do regime colonialista português (1974/1975) que liberaram o Brasil para uma política de aproximação com a África Negra. O evento simbólico, que marcou o início de uma diplomacia autônoma e ativa no continente africano, foi o reconhecimento do primeiro governo independente de Angola, em novembro de 1975, ainda no governo militar. A segunda data, foi o fim do apartheid, vinte anos depois, que permitiu ao Brasil, e à todas as demais potências capitalistas, livrar-se da hipocrisia de condenar nos fóruns internacionais o regime racista e, simultaneamente, manter vínculos econômicos lucrativos com aquele país (Penna Filho, 2002b).

Desta forma, a partir de 1994, as relaçôes bilaterais Brasil-África do Sul vão experimentar uma "nova era". Iniciando-se com o Acordo de Pretória e a visita de Fernando Henrique Cardoso ao país, em 1996, a primeira de um presidente brasileiro, seguindo-se o adensamento das relações comerciais, as negociações Mercosul e SADC, e a visita de Luís Inácio Lula da Silva em 2003. No plano multilateral, uma das principais arenas de reingresso da África do Sul à sociedade das nações, à cooperação Brasil-Índia se agregará a África do Sul nos temas da reforma do Conselho de Segurança e do regime de comércio, culminando com o estabelecimento do G-20, em Cancun, sob a liderança destes três países e a formação do Fórum IBSA, ambos em 2003. (Guimarães, 2000; Penna Filho, 2002a; e Santos, 2002).

Se o regime de apartheid gerou uma ambigüidade no plano das relações interestatais, o mesmo não ocorreu no da sociedade civil. Tanto 
no Brasil quanto na África do Sul, um dos principais núcleos de resistência aos respectivos regimes vigentes surgiu no interior do movimento sindical. Em ambos os países, o aparecimento do "novo sindicalismo", no final dos anos 70, foi quase simultâneo no tempo: a formação da Central Única dos Trabalhadores, CUT e do Partido dos Trabalhadores, PT, por um lado e da Federação dos Sindicatos Sul-Africanos, Fosatu, por outro. Esta coincidência gerou uma cooperação relativamente intensa entre ambos movimentos, em particular a partir do início dos anos 80, quando o Congresso dos Sindicatos Sul-Africanos, Cosatu, realizou uma visita não oficial ao Brasil. Ainda que as respectivas estratégias políticas dos dois movimentos sindicais fossem distintas, a Cosatu reconheceu a importância estratégica desta cooperação. Á medida que se consolidavam os processos de transição para a democracia em ambos países, também se avolumou e diversificou a cooperação entre os respectivos movimentos sociais: o Movimento dos Sem Terra no Brasil e o Comitê de Terras Nacionais na África do Sul; a cooperação nas áreas de habitação e planejamento urbano envolvendo ONGs sulafricanas e experiências congêneres de governos municipais filiados ao PT; bem como no âmbito da assim chamada sociedade civil global e suas manifestações políticas mais significativas como a realização dos Fóruns Sociais. (Fig, 2002).

Não necessariamente a existência de uma cooperação ativa entre os movimentos sociais de ambos países converge com respeito à pauta da cooperação interestatal. Ainda que os temas da reforma do multilateralismo na segurança e no comércio estejam presente nas agendas dos governos e da sociedade civil, os movimentos sociais aprofundam muito mais a crítica ao déficit de accountability e de representatividade das instituições internacionais. Por outro lado, eles também são bastante críticos das políticas de ajuste e da falta de uma adequada prestação de contas da política econômica de seus respectivos governos. Esta situação constitui uma novidade no âmbito da cooperação sul-sul, anteriormente ancorada unicamente na ação governamental. Por outro lado, esta tensão é positiva, pois pode ajudar a aprofundar o componente democrático das instituições nacionais e multilaterais, para além da agenda minimalista dos governos nacionais. 


\section{Uma "nova geografia mundial"?}

Com esta expressão, empregada pelo presidente Lula por ocasião da criação do G-20, o governo brasileiro não apenas destacou positivamente o movimento da política externa, em coordenação com outros países do Sul, na direção do exercício de um metapoder nas questóes multilaterais de comércio, como sinalizou a novidade da cooperação Sul-Sul no contexto da globalização dos mercados e do pós Guerra Fria. A novidade fica por conta da dimensão do comércio e dos interesses concretos dos países envolvidos. Afinal, o objetivo do G-20 é a liberalização do comércio agrícola, de modo a destravar as negociaçóes de Doha, em curso. Em certo sentido, a expressão condensa os dois papeis internacionais reservados aos países intermediários: o de system-affecting state e o de "grande mercado emergente".

Enquanto alguns analistas brasileiros deploram o retorno, à política terceiro-mundista do Itamaraty dos anos 60 e 70, o próprio ministro das Relações Exteriores se encarrega de desfazer esta identificação. Assim, em várias entrevistas, o chanceler Celso Amorim tem assinalado os elementos novos e pragmáticos, contidos em iniciativas com o G-20 e o G-3. Em uma delas, ao destacar a questão dos subsídios agrícolas e do acesso aos mercados do Norte, como constituindo a solda da ação coletiva do G-20, o ministro eliminou qualquer componente ideológico ao contencioso, repudiando, inclusive, sua representação como uma questão Norte-Sul típica, acrescentando: "se os subsídios são todos impostos pelos países do Norte, eu não tenho culpa, é uma situação muito objetiva”.${ }^{10}$ Especialistas em negociações multilaterais criticam estas iniciativas como um retorno ao passado de uma política principista, terceiro mundista. Para estes, o Brasil deveria abrir mão da coordenação dos países do Sul e concentrar-se na sua condição de demandeur nas negociações agrícolas com os Estados Unidos e União Européia. ${ }^{11}$

\footnotetext{
${ }^{10}$ MINISTÉRIO DAS RELAÇŌES EXTERIORES, Discursos, Artigos e Entrevista. Brasil abriga la esperanza de acoger al Perú en el G-20, disponível em: <http:/www.mre.gov.br>. Ver também: INTER PRESS SERVICE NEWS AGENCY. Celso Amorim: G-8 necesita del Sur si quiere legitimar-se, disponivel em: <http://ipsnoticias.net>.

${ }^{11}$ Ver: ABREU, Marcelo de Paiva. Riscos da nova estratégia brasileira na OMC: falta agenda positiva às alianças do Brasil. O Estado de São Paulo, $1^{\circ} \mathrm{de}$ set/2003.
} 
É curioso que com a crise do modelo de desenvolvimento com base nas importações e a abertura da economia brasileira, os defensores do novo status quo, de um modelo mais integrado aos mercados globais, insistam em visualizar estes dois papéis como antagônicos ou mesmo como soma-zero. Assim, quanto mais o Brasil se aproximasse de uma identidade de system-affecting-state, mais ele estaria se afastando da de mercado emergente. Da mesma forma, a construção de relações estratégicas com os países do Sul é apresentada como substituta das relações com os países do capitalismo avançado, estas sim estratégicas para os interesses do país. $\mathrm{O}$ último argumento crítico consiste em levantar a questão da não complementaridade econômica entre os países do Sul e sua alegada condição de competidores no mercado global.

Da perspectiva do atual governo, a cooperação Sul-Sul não substitui o relacionamento com os EUA e a União Européia (vide a viagem do presidente Lula aos EUA, no primeiro semestre de 2004, para apresentar o Brasil aos investidores internacionais), mas representa uma oportunidade de ampliar o comércio exterior brasileiro. O governo avalia que a proporção atual do comércio do Brasil com os EUA e a União Européia já teria alcançado um valor limite a partir do qual os incrementos seriam apenas marginais. Ao contrário, os novos mercados do Sul apresentariam grande potencial por serem economias com complementaridades naturais. ${ }^{12} \mathrm{~A}$ imagem de vários tabuleiros diplomáticos, parte do acervo diplomático brasileiro tradicional, é retomada neste governo.

Claro está que a iniciativa IBSA, como um exemplo paradigmático da cooperação Sul-Sul, apresenta riscos e oportunidades:

- O aprofundamento das relaçóes comerciais entre os três países certamente vai gerar mais contenciosos entre eles do que no passado quando as relações eram bem mais débeis. A crescente legalização do comércio mundial necessariamente gera maiores impactos domésticos, que tendem a aumentar quanto mais interdependentes são as economias. Por outro lado, ainda que os três países estejam em um nível semelhante de desenvolvimento,

${ }^{12}$ Brasil abriga a esperança de acolher o Peru no G-20. 
não exibem o mesmo grau de competitividade em seu comércio internacional o que pode acabar gerando, entre eles, um padrão centro-periferia nas respectivas trocas bilaterais.

- O adensamento das relações comerciais entre os três não apenas viola a regra da maior centralidade seja do relacionamento centro-periferia, seja das relaçôes com países de uma mesma região. Desta forma, sempre existe o risco de que cada um deles priorize mais suas relaçôes tradicionais com os países do Norte, bem como com seus parceiros regionais.

- A cooperação entre os três no plano multilateral não se estende automaticamente a todas às questóes da agenda de reforma multilateral. Por exemplo, tanto a África do Sul quanto o Brasil renunciaram às armas nucleares, enquanto a Índia já é uma potência nuclear. Por outro lado, algumas diferenças de interesses comerciais entre eles já foram minimizadas em função da coordenação comum, como é o caso da formação do G-20 e os interesses agrícolas diferenciados do Brasil e da Índia.

- A ampliação do G-3 para um G-4, com a inclusão da China, por exemplo, pode ser problemática, pois não apenas a ampliação da coalizão diminui a amplitude dos temas de interesse comum e, portanto, dificulta a coordenação da ação coletiva, como, neste caso, existem particularidades do contexto geopolítico asiático que podem dificultar a coordenação.

- A eventual incorporação dos três em arenas como o G-8 ou mesmo como membros permanentes no Conselho de Segurança das Nações Unidas ainda que represente uma ampliação da presença e da voz de países do Sul, pode gerar problemas em suas respectivas regiōes e não necessariamente é vista pelos demais como um aumento de sua representação política nestes fóruns, mas como uma cooptação dos mais desenvolvidos entre eles. Por outro lado, a incorporação de apenas um ou dois deles enfraqueceria o poder de barganha do G-3 vis-à-vis os países industrializados.

Entre as oportunidades, duas, nos plano multilateral e bilateral, me parecem dignas de nota. 
A despeito das dificuldades em manter a unidade da ação coletiva do G-3, estes três países e outros na categoria de intermediários, constituem um dos principais beneficiários de uma ordem baseada em regras multilaterais, nas questôes de paz e segurança, assim como nas de comércio e desenvolvimento. Diante do crescente apelo às iniciativas unilaterais das grandes potências, bem como do recurso à soluções minilaterais ou regionais por estes mesmo países, por um lado, e do incentivo ao bandwagoning para os pequenos países do Sul, por outro, o fortalecimento do multilateralismo pode acabar dependendo da ação coletiva de países com a África do Sul, o Brasil e a Índia.

Apesar das críticas doutrinárias à cooperação Sul-Sul, as relações entre estes três países constituem uma evidência de que as complementaridades entre eles podem ser maiores que os fatores de competição. Como países intermediários eles já dispõem de uma base industrial complexa, tendo alcançado relativo desenvolvimento tecnológico em alguns setores de ponta. Por outro lado, eles compartilham também de todos os problemas estruturais dos países do terceiro mundo: pobreza, desigualdade e analfabetismo. Esta condição comum cria uma base para a cooperação que é distinta da relação Norte-Sul e que não ocorre com freqüência na cooperação Sul-Sul.

Em sentido figurado, o paradigma da Aids pode encarnar o novo sentido da colaboração entre os países do Sul, na medida em que combina: o aporte de uma indústria de fármacos tecnologicamente desenvolvida (Índia), a tecnologia de novos métodos de tratamento da doença (Brasil) e a demanda por estes serviços de saúde pública, em vista das externalidades que a África do Sul incorre por estar situada no continente onde é maior a incidência da doença. Ademais, o paradigma da Aids também ilustra o novo poder de barganha destes países na negociação multilateral com os países industrializados que, no âmbito da OMC, reconheceram a legitimidade do pleito de se isentar os remédios, fabricados nestes países e utilizados no tratamento da doença, das regras rígidas de propriedade intelectual. 


\section{Referências Bibliográficas:}

ABREU, M. P. O Brasil e o Gatt: 1947-1990. In: ALBUQUERQUE, J.A.G. (org.). Sessenta Anos de Politica Externa Brasileira: Diplomacia para o Desenvolvimento. São Paulo: Cultura Editores Associados, 1996.

. Brazil, the Gatt, and the WTO: history and prospects. In: Conferência The International Relations of Brazil: New Possibilities and Old Constraints. Oxford: Centre for Brazilian Studies, University of Oxford, St Antony's College. 15 $-16 \mathrm{mar} / 1999$.

AMORIM, C. L.N. Entre o Desequilíbrio Unipolar e a Multipolaridade: O Conselho de Segurança da ONU no Período pós-Guerra Fria. In: DUPAS, G. \& VIGEVANI, T. (orgs.). O Brasile as Novas Dimensöes da Segurança Internacional. São Paulo: Editora Alfa-Omega, 1999.

NEVES, J.A. Castro. O Papel do Legislativo nas Negociações do Mercosul e da Alca. In: Contexto Internacional, vol. 25, no. 1, 2003.

CESAR, S.E.M. O Congresso Nacional e a Política Externa Brasileira. Dissertação de Mestrado, Universidade de Brasília. 2002.

FONSECA JR., G. Mundos Diversos, Argumentos Afins: Notas sobre Aspectos Doutrinários da Política Externa Independente e do Pragmatismo Responsável. In: ALBUQUERQUE, J.A.G. (org.). Sessenta Anos de Política Externa Brasileira (1930-1990): Crescimento, Modernização e Política Externa. São Paulo: Annablume/NUPRI/USP, 2000.

FIG, D. Interacciones de la Sociedad Civil a través del Atlántico: El Caso de África del Sur y de Brasil. In: Congresso International da Associação LatinoAmericana de Estudos Africanos e Asiáticos, ALADAA. 2002.

GARCIA, E.V. O Brasil e a Liga das Naçôes (1919-1926). Porto Alegre/Brasília: Ed. da Universidade/UFRGS/Fundação Alexandre de Gusmão/Funag, 2000.

GUIMARÃES, S.P. (org)., África do Sul: visōes brasileiras. Brasília: IPRI/Funag, 2000 .

GUIMARÃES, S. P. (org.). Brasil e África do Sul: riscos e oportunidades no tumulto da globalização. Brasília: CNPq/IPRI/MRE. 1996.

HIRST, M. Intermediate States, Multilateralism and International Security. In: Seminário The Role of Brazil in the Fields of Peace and Security. Rio de Janeiro: Iuperj, apoio: Fundação Ford. 22 de mar/2004. 
HERZ, M. O Brasil e a Reforma da ONU. Lua Nova, no. 46, 1999.

KEOHANE, R. Lilliputian's Dilemmas: Small States in International Politics. In: International Organizational, vol. 23, no ${ }^{\circ}$ 2, primavera, 1969.

KRASNER, S.D. Structural Conflict: Third World Against Global Liberalization. Los Angeles: University of California Press. 1985.

LAFER, C. A identidade internacional do Brasil e a politica externa. São Paulo: Editora Perspectiva. 2001.

LIMA, M.R.S. The Political Economy of Brazilian Foreign Policy: Nuclear Energy, Trade and Itaipu. Ph. D. Dissertation, Nashville: Vanderbilt University, TN. 1986.

SILVA, A. de Mello e. O Retorno do 'Destino Manifesto': O Brasil Face à Reforma do Conselho de Segurança da ONU. In: XXII Encontro Anual da ANPOCS. Minas Gerais: Caxambu. 27-30 de out/1998.

PENNA, Filho, P. African Renaissance e a política externa sul-africana nos anos 1990. In: Congresso Internacional da Associação Latino-Americana de Estudos Africanos e Asiáticos, ALADAA. 2002a.

. A Evolução das Relações entre o Brasil e a África do Sul - de 1918 a 2000. In: Congresso Internacional da Associação Latino-Americana de Estudos Africanos e Asiáticos, ALADAA. 2002b.

PINHEIRO, A.C. \& MOREIRA, M.M. Investimentos e comércio BrasilÁfrica do Sul: Presente e Futuro. In: GUIMARÃES, S. P. (org.). Brasil e África do Sul: riscos e oportunidades no tumulto da globalização. Brasília: CNPq/IPRI/ MRE.1996.

SANTOS. O Poder Legislativo no Presidencialismo de Coalizão. Belo Horizonte: Ed. UFMG. 2003. 
SANTOS, J.S. A África do Sul e a Integração Regional na África Austral. In: Congresso Internacional da Associação Latino-Americana de Estudos Africanos e Asiáticos, ALADAA. 2002.

SARDENBERG, Ronaldo Mota. O Brasil e as Nações Unidas. In: ALBUQUERQUE, J.A.G. (org.). Sessenta Anos de Politica Externa Brasileira (1930-1990): Prioridades, Atores e Politicas. São Paulo: Annablume/NUPRI/ USP. 2000.

SENNES, R.U. Brasil, México e India na Rodada Uruguai do Gatt e no Conselho de Segurança da ONU: um estudo sobre os paises intermediários. Tese de Doutoramento, São Paulo: Universidade de São Paulo, set/2001.

SOUZA, A. A Agenda Internacional do Brasil: um Estudo sobre a Comunidade Brasileira de Politica Externa (mimeo). Rio de Janeiro: CEBRI. 2002.

\section{Resumo}

No artigo se examina a relação entre o Brasil, a África do Sul e a Índia, que apesar de apresentarem diferenças internas e históricas, são vistos como potências regionais, com relevante impacto na conjuntura internacional, principalmente na função de interlocutor entre as grandes e pequenas potências. Com um especial enfoque na política brasileira, revela uma semelhança entre a política externa dos dois últimos governos (FHC e Lula) quanto a estratégias de estabilidades na agenda diplomática, e ainda pela posição tradicional frente aos mecanismos multilaterais.

\section{Abstract}

The article examines the relations among Brazil, India and South Africa, that, despite historical internal differences, are regarded as regional powers, with relevant impact on the international conjuncture, specially when functioning as interlocutors for great and small States. With a special emphasis on Brazilian foreign politics, it discloses similar patterns comparing foreign politics in Brazil in the past two governments (FHC and Lula), regarding stability strategies in the diplomatic agenda and the traditional position assumed when dealing with multilateral mechanisms

Palavras-chave: Brasil, Índia, África do Sul, Cooperação, Multilateralismo Key words: Brazil, Índia, South Africa, Cooperation, Multilateralism 